\title{
Berthold of Moosburg, the unum animae, and Deification
}

\author{
Loris Sturlese \\ Accademia Nazionale dei Lincei, Rome
}

\section{Introduction. Berthold of Moosburg's Commentary on Proclus}

In the first chapter of the Ecclesiastical Hierarchy, Dionysius defines deification as follows: "Deification is assimilation and union with God, as far as possible"." In the Middle Ages, the theme of deification provoked orthodoxy to issue numerous condemnations of doctrines that were believed not to safeguard the transcendence of God. In the 14th century, which is the period on which we will focus, the debate concerning the heresy of the so-called "free spirit" was particularly lively in the Flemish Rhineland religious and cultural environment, and took place both in Latin and in the vernacular. An authoritative participant in this debate was the Dominican Berthold of Moosburg. We know little about his biography, but enough to recognise him as a pivotal figure in this discussion: he was active in the intellectual leadership of the Dominican order in this period, he succeeded Eckhart at the Dominican studium generale of Cologne, he had the task of "collecting the pieces", so to speak, after the condemnation of Eckhart, he was involved in the spiritual direction of the Beguines of Cologne, and he was well-known in the mystical circles of Bavaria. ${ }^{2}$

He has written only one work, a gigantic Exposition of the Elements of Theology of Proclus. ${ }^{3}$ The Elements of Theology is a metaphysical work par

1 Dionysius, De ecclesiastica hierarchia, ed. G. Heil (Berlin / New York: De Gruyter, 1991), 1.3, p. 66, l. 12-13; Lat. trans. in Dionysiaca, recueil donnant l'ensemble des traductions latines des ouvrages attribués au Denys de l'Aréopage, ed. Ph. Chevallier (Bruges: Desclée de Brouwer, 1937), p. 109 o.

2 For a biographical account of Berthold, see L. Sturlese, Homo divinus. Philosophische Projekte in Deutschland zwischen Meister Eckhart und Heinrich Seuse (Stuttgart: Kohlhammer, 2007), p. 137-138; E. King, Supersapientia. A Study of the Expositio super Elementationem theologicam Procli of Berthold von Moosburg, PhD diss. (University of Cambridge, 2016), p. 5-14.

3 Berthold of Moosburg, Expositio super Elementationem theologicam Procli. Prologus. Propositiones 1-13, eds M.R. Pagnoni-Sturlese, L. Sturlese (Hamburg: Meiner, 1984); Berthold of Moosburg, Expositio super Elementationem theologicam Procli. Propositiones 14-34, eds L. Sturlese, M.R. Pagnoni-Sturlese, B. Mojsisch (Hamburg: Meiner, 1986); Berthold of 
excellence, and Berthold's mission is to detect the immutable structures that found the world of experience. The discovery, piece by piece, of this transempirical and foundational metaphysical complex has the same effect, in the end, of being able to contemplate, behind the curtain of a theatre, the enormous quantity of interconnected mechanisms and artifices that with their immutable presence make possible the story that from time to time takes place in the manifold appearances of becoming. The aspect of immutability prevails in this fundamental and foundational presence - the immutability of an order that begins with the One, which by its causal transcendence establishes a One-Good, from which derives a more determined Unity and so on as far as the institution of a finite series of henads (seven), which constitute the primordial causes from which further series of unparticipated and participated principles derive. The look behind the scenes of the universe allows Berthold to identify, between the transcendent One and Matter, a numerical detail of something like 126 metaphysical principles dependent on each other and made up of orders (monarchies) dependent on the primordial causes (unity, infinity, entity, vitality, intellectuality, animality, and physicality). But beyond these complicated details - for which we can well refer to Ezequiel Ludueña's dissertation ${ }^{4}$ - it is important to note, as I said, the aspect of immutability, because even as we descend from eternity to time and from motionlessness to movement (soul), we have yet to consider the eternal and immutable motion of the celestial spheres.

What, then, does this discovery mean, what is the sense of the contemplation of these dusty and complicated mechanisms of the intelligible universe? Is it one of the many contributions - to use the words of E.R. Dodds 5 - "to that most extensive of all sciences, the Wissenschaft des Nichtwissenswerthen"?

Moosburg, Expositio super Elementationem theologicam Procli. Propositiones 35-65, ed. A. Sannino (Hamburg: Meiner, 2001); Berthold of Moosburg, Expositio super Elementationem theologicam Procli. Propositiones 66-107, ed. I. Zavattero (Hamburg: Meiner, 2003); Berthold of Moosburg, Expositio super Elementationem theologicam Procli. Propositiones 108-135, ed. F. Retucci (Hamburg: Meiner, 2011); Berthold of Moosburg, Expositio super Elementationem theologicam Procli. Propositiones 136-159, ed. F. Retucci (Hamburg: Meiner, 2007); Berthold of Moosburg, Expositio super Elementationem theologicam Procli. Propositiones 160-183, eds U.R. Jeck, I.J. Tautz (Hamburg: Meiner, 2003); Berthold of Moosburg, Expositio super Elementationem theologicam Procli. Propositiones 184-211, ed. L. Sturlese (Hamburg: Meiner, 2014).

4 See E. Ludueña, La recepción de Eriúgena en Bertholdo de Moosburg. Un aporte sobre la Escuela de Colonia, (Saarbrücken: Publicia, 2013), p. 122-224.

5 E.R. Dodds, "Introduction" to Proclus, The Elements of Theology (Oxford: Clarendon Press, $\left.1963^{2}\right)$, p. ix. 
What is its relevance to understanding man, to understanding the human condition?

The question seems legitimate, if we think that in the historical moment in which Berthold lives, the way of understanding the human being and his relationship to God is changing. The "free spirit" proposes a path of individual deification; the Council of Vienne condemns the thesis that "Any intellectual creature in itself is blessed by nature, and the soul does not need a light of glory to raise it to see God". ${ }^{6}$ Dietrich of Freiberg wonders if there is a personal principle with which we unite ourselves to God in the beatific vision and answers that it is the individual agent intellect, which contemplates God by nature; ${ }^{7}$ Eckhart proposes to overcome the false autonomy of individuality by recognising the absolute relational dependence of man on God. ${ }^{8}$

In his Exposition, Berthold speaks of deification, theosis, according to a broad spectrum of understanding: as a possibility of the subject in the twofold aspect of union with God in the present and in the future life, and this under the twofold perspective of the subject's belonging to the pagan and to the Christian tradition, that is to say to the state of (corrupted) nature and to the state of (reintegrated) grace. He deals with all these themes of contemplation in this life and in the afterlife, he reflects on important mystical passages from Dionysius and Richard of Saint Victor, he quotes Bernard's metaphor of mixed liquids, he knows Eriugena's doctrine of deification: in short, the whole mystical tradition is known to him.

The Doctrine of Dionysius the Areopagite on the Three Movements

Berthold's intention may be better clarified by considering his doctrine of the "three movements" of the soul. The doctrine was sketched by Dionysius and was interpreted by his commentators in different ways. Dionysius' relevant text is reported in three different places of the Exposition: the first in the Expositio tituli, the second in Proposition 131, the third in Proposition 185 (literal quotation). ${ }^{9}$ The text quoted in the Expositio tituli is the following:

6 Enchiridion Symbolorum. Definitionum et declarationum de rebus fidei et morum, eds H. Denzinger, A. Schönmetzer, 36th ed. (Barcelona / Freiburg im Breisgau / Roma: Herder, 1976), p. 282, §895.

7 King, Supersapientia, p. 21, 37-42.

8 King, Supersapientia, p. 21, 140.

9 Berthold of Moosburg, Expositio, 131A, p. 19o, l. 10-p. 191, l. 39; Berthold of Moosburg, Expositio, ${ }_{185} \mathrm{~K}$, p. 26, l. 393-408; for the Expositio tituli, see the following note. 
Sunt autem istorum motuum, inquantum sunt animae, definitiones tales, secundum quod pertractat Dionysius ubi supra: "Circularis quidem est animae ad se ipsam introitus ab exterioribus et intellectualium ipsius virtutum uniformis convolutio sicut in quodam circulo non errare ipsi largiens, in multis exterioribus ipsam etiam congregans primum ad se ipsam, deinde sicut informem factam uniens unitive unitis virtutibus et ita ad pulchrum et bonum manuducens, quod est super omnia existentia et unum et idem et sine principio et interminabile. Oblique autem anima movetur, inquantum secundum proprietatem suam divinis illuminatur cognitionibus, non intellectualiter et singulariter, sed rationabiliter et diffuse et sicut commixtis et transitoriis operationibus et ab exterioribus sicut a quibusdam signis variatis et multiplicatis ad simplices et unitas sursum agitur contemplationes. In directum autem, quando non ad se ipsam ingressa et singulari intellectualitate mota - hoc est enim, sicut dixi, secundum circulum -, sed ad ea, quae sunt circa ipsam, progreditur.".

According to Dionysius De divinis nominibus c. 4, angels and human souls have a threefold mental movement: ${ }^{11}$ the movement of human souls is what interests Berthold particularly, because souls are part of the order of nature (natural providence) and angels are not.

The first movement, the circular one, is a concentration on interiority (animae ad se ipsam introitus) that leads to the contemplation of the Good that transcends the whole of being (super omnia existentia).

The second movement, the oblique or helical one, is the speculative movement of rational and deductive reflection (non intellectualiter et singulariter, sed rationabiliter et diffuse), which - Berthold points out - by the signs offered by the external world is enlightened and raised to simple and unitive contemplations (ad [...] unitas sursum agitur contemplationes).

The third direct movement takes place "when it progresses to the things that are around it" (In directum autem, quando [...] ad ea, quae sunt circa ipsam, progreditur [sic!]).

As we have already said, Berthold literally quotes the text of Dionysius twice. The first quotation occurs in the Expositio tituli (the text reported above), and refers to Proclus himself, who would have experienced the three movements in person (his writings being proof of this); the second occurrence refers more generally to the possibilities of the soul according to the state of the present

10 Berthold of Moosburg, Expositio, Expositio tituli A, p. 38, l. 35-48.

11 Dionysius, De divinis nominibus, ed. B.R. Suchla (Berlin / New York: De Gruyter, 1990), 4.8-9, p. 153, l. 4-p. 154, l. 6; Dionysiaca, p. 189-19o. 
life (de anima secundum statum praesentis vitae). The long quotation (134 words) appears to be taken directly from the Corpus Dionysiacum (translation by John Saracen), but the comparison with the original reveals a significant discrepancy: the phrase "et ab exterioribus sicut a quibusdam signis variatis et multiplicatis ad simplices et unitas sursum agitur contemplationes", which in the original text of Dionysius refers to the straight movement, is placed in Berthold's text at the conclusion of the oblique movement (italics in the text reported above). The fact seems to me to be very important. In this way the direct mystical intuition (characteristic of the straight movement) is attributed as a prerogative of the oblique movement, which is that of philosophical reason.

It is difficult to think that this is a random coincidence. Berthold certainly had a complete text "in order": this is demonstrated by the fact that in a similar place ${ }^{12}$ he clearly states that the rectilinear movement is proper to direct mystical intuition. Therefore we must conclude that the displacement is intentional - and this displacement changes the cards on the table with respect to Dionysius! Evidently Berthold is keen to communicate that the movement of philosophical reason can land (or rather: in fact lands) at the mystical vision. So far, so good. For now we can continue to deepen the doctrine of the three movements and its application to the historical Proclus.

\section{3}

\section{The Three Movements of the Soul According to Thomas of York}

Those who are familiar with Dionysius and the tradition of his commentators might be amazed to find me writing that the straight movement leads to the mystical vision of God. I confirm, for Berthold it is just like that. It is an interpretation that finds no confirmation either in the Commentaries of Albert the Great or of Thomas Aquinas, but that Berthold derives from the Sapientiale of Thomas of York, which has recently been discovered to be one of his most important doctrinal sources. At the time when the first volumes of the Expositio edition were produced, the influence of Thomas of York on Berthold was not yet known. The research of Retucci, Porreca, and King has highlighted the many places where the Sapientiale is used, and this is also the case regarding the three movements of the soul. ${ }^{13}$

\footnotetext{
12 Berthold of Moosburg, Expositio, 131A, p. 191, l. 35-44.

13 See F. Retucci, "Magister Thomas Anglicus minor", in Berthold of Moosburg, Expositio super Elementationem theologicam Procli. Propositiones 136-159, p. xxiii-xxxix; D. Porreca, "Hermes Trismegistus in Thomas of York. A 13th-Century Witness to the Prominence
} 
Thomas of York addresses the question of the threefold movement in chapter 6 of the first book of the Sapientiale. ${ }^{14}$ His aim is to show the breadth of the natural knowledge of God achieved by the philosophers of antiquity (divinitatis agnitionem) and his argument is based on the perception of nonself-sufficiency that the subject feels both by practicing introspection (circular) and reflection upon the world of the senses: the oblique with the effort of discursive rational procedure, the straight with an ascent that leads to direct vision. In all three cases, the subject feels a failure that is the engine of a search that leads to the recognition of the existence of the first principle, God. Thomas' passages have been carefully examined by Evan King, ${ }^{15}$ to whom I can refer hoping that his beautiful dissertation will soon be published. I will limit myself to pointing out a couple of elements characteristic of Thomas of York's interpretation. The three movements refer to the knowledge of the existence (anitas) of God, and have been practiced by the philosophers of antiquity to a large extent, particularly the first (introspection) and the second (philosophical reason). The straight movement, on the other hand, in the case of those who did not have the faith, was granted only to a few, and in its excellence, only to very few, by special grace, that is, as a consequence of the completeness and perfection of the oblique movement. Note that Dionysius, in De divinis nominibus, makes no mention of the philosophers of antiquity. It is true indeed that Dionysius had been, before conversion, a pagan philosopher. But the functionalisation of this doctrine to formulate the notion of a sort of philosophical revelation of pagan wisdom is the original work of Thomas of York and does not seem to me to be reflected in the exegesis of the Corpus Dionysiacum at all. At the center of Thomas' reflection is the universal consensus of the people on the anitas of God, and that this "ascent in the knowledge of divinity" can lead to a mystical vision is a theme present, but not developed in the Sapientiale. Thomas is especially interested, I think, in the oblique movement.

Berthold was fascinated by Thomas' reading of Dionysius. But it was the study of Proclus' Opuscula (as we know, the manuscript he owned and glossed is still preserved in the library at Basel $)^{16}$ that opened his eyes, so to speak. In

of an Ancient Sage", in Archives d'histoire doctrinale et littéraire du Moyen Âge 72(2005), p. 147-275; King, Supersapientia, p. 28-43.

14 See Thomas of York, Sapientiale, ed. F. Retucci, lib. I, c. 6 (Firenze, in press).

15 King, Supersapientia, p. 31-34.

16 Ms Basel, Universitätsbibliothek, F.IV.31. See King, Supersapientia, p. 3-9. 
De fato et providentia in particular, Berthold thought he had found the key to understanding the doctrine of Dionysius, in particular to further develop the interpretation of the straight movement sketched by Thomas.

In the Expositio tituli, Berthold carefully relates the three movements of the soul with what Proclus wrote, highlighting the similarities with the text of Dionysius. In the case of the circular movement, Berthold emphasises the almost literal correspondence between De fato and De divinis nominibus:

Quod autem Proclus per primum motum, scilicet circularem, [...] ascenderit, patet in libro suo De fato et providentia 6 cap., [...] dicens: [...] conversa est ad se ipsam, [...] ad ipsam iam summam recurrens ipsius intelligentiam, [...] videt autem supra omnes animas intellectuales substantias et ordines [...] videt autem rursum et ante haec eas, quae supra intellectum, deorum ipsorum monades. ${ }^{17}$

This is the movement of intellect that leads to the contemplation of the primordial causes of Eriugena. The oblique movement is formulated in the exact terms of Thomas' philosophical reasoning, and is identified par excellence with the theorems of the Elements of Theology:

per motum obliquum, qui proprius erat philosophorum et erat per laboriosam investigationem primi omnium existentium principii dividendo, definiendo, communibus principiis utendo, a notis ad ignota per ratiocinationem progrediendo, a sensibilibus ad intelligibilia ascendendo et inter intelligibilia ab uno in aliud tendendo, quousque ad simpliciter ultimum perveniatur. ${ }^{18}$

This arrival to the extreme limit leads to a mystical vision. The rectilinear movement is interpreted as a mystical vision and as the exercise of an individual transintellectual principle: ${ }^{19}$

Sed quod per directum motum ascenderit in Dei cognitionem [...] non digressive, sed unitive, hoc est [...] directa ipsius visione, apparet libro quo supra cap. 8, ubi [...] prosequitur de cognitione, quae est supra intellectum, quam theologi etiam ante Platonem divulgant vocantes eam ut veri

17 Berthold of Moosburg, Expositio, Expos. tit. B, p. 38, 1. 49-p. 39, l. 67 (italics added for emphasis), citing Proclus, De providentia, ed. H. Boese, Tria opuscula (De providentia, libertate, fato) (Berlin: De Gruyter, 196o), c. 6, §18, p. 124, l. 2-p. 126, l. 8, and c. 6, §19, p. 126, 1. 8-9.

18 Berthold of Moosburg, Expositio, Expos. tit. D, p. 40, l. 110-115.

19 Berthold of Moosburg, Expositio, Expos. tit. C, p. 39, l. 73-p. 40, 108. 
divinam maniam: "Ipsam enim aiunt unum animae, non adhuc intellectuale excitantem", sed coaptantem ipsum unum uni summo, cui "adiacens le unum quietem amat, clausa cognitionibus, muta facta et silens intrinseco silentio". ${ }^{20}$ His concordat Dionysius 7 cap. De divinis nominibus B et $4 N^{21}$

As we can see, according to Berthold, Proclus experienced the direct vision of God (directa ipsius visione).

A very significant shift here should be noted: Dionysius spoke of the mystical experiences of himself and his friends, Timothy, Dorotheus, Gaius. Thomas of York applied this in a generic way to the philosophers of antiquity. Berthold focuses it on Proclus, and does so on the basis of a philological textual comparison. The description of Dionysius fits perfectly with Proclus, who becomes the prototype of the "divine man", homo divinus (of which Dionysius speaks). At least on a couple of occasions Berthold points out that in Proclus' texts there is the key to fully understand Dionysius' position: "Sed auctor expressius hoc deducit $\left[\ldots . .{ }^{22}\right.$ Istam intentionem clarius ponit Proclus".23

This shift has the appreciable advantage of allowing Berthold to bring some clarity to the group of ancient authors (Seneca, Cicero, Apuleius, Macrobius, etc.), which Thomas of York offers in a way that is as inclusive as it is undifferentiated. The reading of Proclus (one should recall that he was still unknown to Thomas) offers Berthold the possibility of resolving the question of ancient wisdom and the Platonic tradition in a selective way, with a surgical operation that identifies and isolates the three movements in the historical instantiation of the Platonic Proclus Diadochus. Thomas of York attributed the vision of God to "a few", or better to "a very few" pagans, and above all put the accent on the consensus philosophorum. In Berthold, this consensus is transformed into the historical-factual proof of the personal deification carried out by a pagan philosopher, and by a long and ancient pre-Platonic and Platonic tradition.

To ask how Proclus managed to do what (as Tauler will say) many Christians are unable to do (and which, according to Tauler again, should be a shame for them), ${ }^{24}$ is tantamount to asking - beyond the obvious need for the grace of God - the metaphysical reasons and the psychological foundations of deification. This is what we will try to deepen by studying the third, direct movement.

\footnotetext{
$20 \quad$ Proclus, De prov., c. 8, §31, p. 139, l.1-p. 140, l. 12.

21 Dionysius, De div. nom., 7.1, p. 194, Dionysiaca, p. 385-386; De div. nom., 4.11, p. 156-157, Dionysiaca, p. 206.

22 Berthold of Moosburg, Expositio, 2oH, p. 71, l. 245-p. 72, 246.

23 Berthold of Moosburg, Expositio, 129B, p. 178, 1. 167.

24 See Sturlese, Homo divinus, p. 169-197.
} 
We can anticipate that, according to Berthold, Proclus so to speak "activated" and exercised a cognitive principle that is inherent to every human being, the exercise of which was already known to the ancient pre-Platonic philosophers and to Plato, and which the subsequent victory of the Aristotelian vision of the world has condemned to oblivion: this principle is the unum. The unum is the foundation of both the straight and the oblique movement. We understand now the reason why Berthold unites the two moments under a single denominator of the "beatific vision", intentionally modifying Dionysius' text, as we have seen.

It is therefore certainly true that, as Stephen Gersh pointed out, ${ }^{25}$ Berthold reads Proclus through Dionysius, but from these considerations it appears equally true that at least in this case he reads Dionysius through Proclus.

\section{The Straight Movement and the unum animae}

We have seen that, in the text of Dionysius used by Berthold, the straight movement is formulated in an obscure and even mutilated way, and that its interpretation is also open to debate; but it is nevertheless beyond doubt that Berthold understands this movement as that of a unitive (unitive) and direct vision (directa ipsius [Dei] visione). In fact, he tells us that the straight movement is rooted in a particular cognitive principle, of which Dionysius speaks in De divinis nominibus c. 7 , and which is called "unity" transcending the nature of the mind (unitas superexaltata, a Proclean term). This is a "unity" that abandons intellectual knowledge (intellectuales virtutes sunt superfluae) and is capable of bringing multiplicity back to the one (multorum ad unum convolutio), becoming deiform and launching itself into the inaccessible light (deiformis facta [...] luci se immittit) ${ }^{26}$ - note that, according the commentators, this idea is rather the characteristic of the circular movement. On the basis of his reading of

25 S. Gersh, "Berthold von Moosburg and the Content and Method of Platonic Philosophy", in J. Aertsen, K. Emery, Jr., A. Speer (eds), Nach der Verurteilung von 1277. Philosophie und Theologie an der Universität von Paris im letzten Viertel des 13. Jahrhunderts (Berlin / New York: De Gruyter, 2001), p. 493-503, at p. 502.

26 Berthold of Moosburg, Expositio, 20H, p. 71, 1. 238-245: Corpus autem, animam et intellectum esse in homine non est, qui ambigat. Sed quod sit ibi unum, testatur Dionysius 7 cap. De divinis nominibus $B$ vocans ipsum «unitionem excedentem mentis naturam (vel «unitatem superexaltatam», ut dicit alia trans(atio), per quam mens coniungitur ad ea, quae sunt supra ipsam»; et hoc «multorum ad unum convolutione», ut dicit infra $C$; unde et intellectuales virtutes sunt superfluae, «quando anima deiformis facta per unitionem ignote inaccessibili lucis lumini se immittit», ut dicit 4 cap. $N$. For the Dionysian source see above, note 21. 
Proclus' Opuscula, ${ }^{27}$ Berthold adds that this is the same cognitive principle of which Proclus treats in chapter 8 of De fato, namely a movement of the mind that abandons and transcends intellectual knowledge (non adhuc intellectuale excitantem) and joins the One (coaptantem uni) in stillness and inner silence, thus becoming God as far as possible and living by divine life (deus factus, ut animae possibile). The closeness to the text of Dionysius is indeed impressive. Berthold notes that this cognitive principle bears the same name in both authors: Dionysius speaks of a "unity", Proclus of an unum in the soul, evoking the name that the tradition of pre-Platonic theologians and Plato himself gave it.

Proclus also converges with Dionysius in pointing out that the "one of the soul" is hidden from common sense, and indicates the reason why: people live only within the horizon of the (Aristotelian) world of being (Dionysius: in existentibus sunt firmati) ${ }^{28}$ here below (Proclus: circa ea, quae deorsum, volvuntur), and therefore are incredulous (Proclus: increduliter habemus nos) ${ }^{29}$ and ignorant (Dionysius: indoctos). Nevertheless, Berthold states, Proclus offers a clearer formulation (expressius) than that of Dionysius. In what sense?

It is enough to reread the refined analysis of the unum animae offered by Werner Beierwaltes ${ }^{30}$ in his fundamental contribution of 1961 to understand what Berthold might think of. The German scholar based his interpretation on texts by Proclus that were not all known in the Middle Ages. But if we want to limit ourselves to the Opuscula, and in particular to De fato, we note that chapters 6-8, cited in full in the Proposition 185 of the Expositio, ${ }^{31}$ outline a

27 Berthold of Moosburg, Expositio, 20H, p. 71, 1. 245-p. 72, 1. 250: Sed auctor expressius hoc deducit 10 quaest. De providentia in haec verba: «Et enim in nobis iniacet aliquod secretum unius vestigium, quod et eo, qui in nobis est intellectus, est divinius, in quem et consummans anima et locans se ad ipsum divina est et vivit divina vita». Idem habetur De fato et providentia cap. 8, ubi loquitur de mania divina, quam aiunt theologi «unum animae». For the Proclean source see above, note 20.

28 Berthold of Moosburg, Expositio, 71D, p. 35, l. 123-127: Quem quidam firmati in existentibus et non opinantibus aliquid esse super entia dicunt fore esse, sicut dicit auctor De causis: 'Prima rerum creatarum est esse'. Esse autem est actus entis. Sed tales vocat Dionysius indoctos, in 1 cap. De mystica theologia, ubi dicit sic: Istos autem dico (subaudi: indoctos), qui in existentibus sunt firmati nihil super existentia supersubstantialiter esse opinantes'.

29 Berthold of Moosburg, Expositio, 121M, p. 111, l. 212-215: [...] deus factus, ut animae possibile, cognoscet solummodo, qualiter dii omnia indicibiliter cognoscunt singuli secundum li unum, quod sui ipsorum. Donec autem circa ea, quae deorsum volvimur, increduliter habemus nos circa haec, scilicet omnia divino cognoscente.

30 W. Beierwaltes, "Der Begriff des unum in nobis bei Proklos", in P. Wilpert (ed.), Die Metaphysik im Mittelalter. Ihr Ursprung und ihre Bedeutung (Berlin / New York: De Gruyter, 1963), p. 255-266.

31 Berthold of Moosburg, Expositio, 185L, p. 26, l. 410-p. 28, 1. 455. 
rigorous philosophical itinerary of the rational soul's self-reflection which, on the basis of the principle that "what is united presupposes a cause of union, and what has an intellectual nature presupposes an intellectual power, and everything that is a participant presupposes a non-participable hypostasis,", 32 ascends from sensitive to discursive knowledge and from that to intellectual noesis, to reach the ground, the foundation, the One: "become therefore one, to see the one, or rather not to see the one: in fact, he who sees will see something of intellectual nature and not above the intellect, and will include a certain one and not the absolute One". ${ }^{33}$ The one of the soul is therefore revealed to be a condition of the very possibility of sensitive and rational experience, and as the point of arrival of a process of self-reflection that also represents a profound diagnosis of the human condition.

This is also the conclusion reached by the oblique movement expressed in the Exposition on the Elements of Theology: in fact, from the metaphysical point of view, the one in us is a "shining" instituted by the self-determination of the First Principle (the One-Good) in the series of primordial causes and in particular in the Primary Soul, which institutes the Soul for itself and a double series of souls, a finite series and a series of "shinings" in human souls. ${ }^{34}$

In sum, according to Berthold, the one of the soul (Proclus), the unity transcending the nature of the mind (Dionysius) is inherent to the nature of man. The human condition is no less and no more than that of living in the unawareness of bearing within oneself a secret vestige of the One. The task of philosophical theology is to bring the One to awareness. This does not mean "seeing it" or even "thinking about it", because the One is the condition of the possibility of "seeing" and "thinking", and awareness of this is nothing more than identity with the One in stillness and silence. At this point I will be careful not to violate the threshold of the unsayable and of silence, but I think it is at least appropriate to make an explanatory observation. This concerns the providential dimension of the unum animae as a "shining" of the One itself, and it appears important to clarify the trans-Aristotelian sense of the Proclean doctrine also in relation to the discussions of Berthold's German contemporaries.

We have seen that the most striking character of the presentation of unum animae is its logical-ontological primacy with respect to the Aristotelian

32 Berthold of Moosburg, Expositio, 185L, p. 27, 1. 444-446: Oportet enim supra unita locari unificas causas et supra intellectuales factas intellectualificas, et supra omnia simpliciter participantia imparticipabiles hypostases.

Berthold of Moosburg, Expositio, 197G, p. 137, l. 170-172: Fiat igitur unum, ut videat le unum, magis autem, ut non videat le unum: videns enim intellectuale videbit et non supra intellectum, et quoddam unum intelliget et non le antounum.

Berthold of Moosburg, Expositio, 64F, p. 197, l. 155-p. 198, l. 183 . 
intellect. On this point, which appears to be very characteristic if we consider the role that Dietrich and Eckhart assign to the intellect, it should be noted that Berthold distinguishes, on the basis of Proclus, an "intellectual" cognition from a "providential" cognition. The first is proper to the intellect, and Berthold here fully accepts the doctrine of Dietrich's so-called "paradoxes of consciousness" (Paradoxien des Bewußtseins): ${ }^{35} 1$ ) the intellect always constitutes itself in thinking itself in act; 2) in this intellection the intellect thinks itself by essence; 3 ) the intellect is an actual image of the totality; 4) and the intellect by thinking itself thinks the totality by a simple intellection.

The "providential" cognition is "the knowledge of providence that transcends the intellect and is proper to the One only, according to which each god is and is said to provide for things, and that places itself in an operation prior to the intellect". ${ }^{36}$ It is always a matter of the knowledge of totality, like that of the intellect, but not in terms of just knowing, but in terms of providere (to provide), which is "the act or operation of Good" (providere est actus sive operatio boni), 37 "an operation of Good that gives each entity what is appropriate to it" (providentia [...] 'operatio boni unicuique congrua largientis'). ${ }^{38}$ The providence of the unum animae is therefore an imitation and participation in the divine power that establishes and preserves totality as goodness and order, and this is deification. ${ }^{39}$

35 See K. Flasch, "Einleitung", in Dietrich of Freiberg, Opera omnia, vol. 1. Schriften zur Intellekttheorie, ed. B. Mojsisch (Hamburg: Meiner, 1977), p. xiii. See Dietrich of Freiberg, De visione beatifica, ed. B. Mojsisch, in Opera omnia, vol. ı. Schriften zur Intellekttheorie, 1.1.1.3.6, p. 22, l. 100-120.

36 Berthold of Moosburg, Expositio, 134D, p. 216, l. 70-73: providentiae cognitio super intellectum existens et uno solo, secundum quod et est unusquisque deus et providere omnium dicitur in ea, quae ante intelligere operatione sistens se ipsum. Hoc itaque uno, secundum quod et consistit, cognoscit omnia. Cf. Proclus, De decem dubitationibus circa providentiam, ed. H. Boese, q. 1, §4, p. 6, 1. 1-5.

37 Berthold of Moosburg, Expositio, 120F, p. 101, l. 348-349.

38 Berthold of Moosburg, Expositio, 120D, p. 98, l. 259-26o.

39 Berthold of Moosburg, Expositio, 188E, p. 65, l. 203-215: anima [...] non solum vivit animealiter, sed etiam intellectualiter, et per consequens habet in se principium sui motus, scilicet «unum ipsius animae», quod quidam vocant «deiformem unitatem», alii vero «abditum mentis» sive «faciem», quidam autem «intellectum agentem», hoc, inquam, principium manens in se stabile et invariabile et existens intrinsecum substantiae animae, utpote portio eius intranea et eminentior principiat omnem motum vitalem ipsius animae, sive sit intellectualis sive sensualis sive germinalis. [...] Ista enim intraneitas, cum importet mutuum respectum eorum, quorum unum est in alio, non est nisi identitas substantialis. 


\section{Berthold and the Mystics}

With the doctrine of the unum animae, Berthold offered an original solution to the question raised by Dietrich at the end of the 13th century: what is the individual principle through which we unite ourselves to God in the beatific vision? Is the human being naturally "capable of God"? Dietrich's answer is well known: Aristotle (the agent intellect), Augustine (the abditum mentis), and Scripture (the image of God) converge in establishing the principle of the beatific vision as an individual and natural one. In the beatific vision, the individual agent intellect becomes the form of the possible intellect; this condition is, however, denied to the subject during "this life", because "in this life $[\ldots]$ it unites itself to the subject only through the intelligible species that are its action". ${ }^{40}$ In other words, Dietrich says, the human being lives in a condition of alienation from his intellectual and vital principle, which can only be healed in the afterlife when the order of nature is absorbed by that of grace or, in other words, when natural providence is absorbed by voluntary providence. By choosing to keep to the natural order, Dietrich is indeed dealing with the foundation of a possible mystical experience, but he places mysticism outside the horizon of his problematic. And in fact, although he was certainly aware of transitory "mystical" phenomena in his time, he does not mention them, except for a nod to the experience of Saint Benedict, who was reported to have seen the universe at a glance (in ictu oculi). ${ }^{41}$ Dietrich probably considered mystical experiences to be outside the horizon of philosophical theology, that is, belonging to the order of so-called voluntary providence, of ethics and of the intervention of God in the world. Not very different was the position of Eckhart, his great contemporary, who agreed with him in considering the problem of mystical experience to be a marginal one.

Berthold raises with greater force the question of the relationship between the unum, intellect and mystical experience. This can be seen from his interpretation of Dionysius, who teaches how the threefold movement of the soul leads to a direct contemplation of God that happens ( fit), "through a strong contrition, through the abandonment of the senses and intellectual operations, of all the sensible and intelligible, and of all being and non-being, in such a way that the divine man rises in a hidden way, according to his possibility,

40 Dietrich of Freiberg, De visione beatifica, 4.3.3, p. 122, 1. 80-84: nobis quoque, qui degimus in hac vita, non unitur ut forma, secundum quod actio eius est essentia eius, ut dicit Commentator Super III De anima, sed solum unitur nobis per intellecta in actu seu species intelligibiles, quae sunt actio eius, secundum quod actio eius differt ab essentia eius.

Dietrich of Freiberg, De visione beatifica, 1.1.4 (5), p. 29, l. 27-32. 
to the union with the one who transcends all substance and knowledge", and "for this the going-out from himself and from everything is necessary". ${ }^{42}$ Here Dionysius is speaking in the first person of himself and his friends, and therefore of an experience in the present life. In this way, Dietrich's problem regarding the "principle by which we unite ourselves to God in the beatific vision" 43 in the future life moves to the "principle of union in the present life". The problem is made even more acute because, according to Berthold, a philological reading of Dionysius shows that the term unitio (union as an abstract deverbal noun, Ein-ung, the action of uniting) used by John Saracen is, in the older translation of Eriugena, unitas (unity as an abstract deadjectival name, Ein-heit) that transcends the intellect. The lectio of Eriugena corresponds exactly to that of Proclus (unum animae). And this unum, as we know from Dietrich's analysis, is a principle and essential cause of the intellect of the soul; it cannot be an accident, but it is a substance. ${ }^{44}$

42 Berthold of Moosburg, Expositio, 202A, p. 181, l. 27-p. 182, l. 35: Istam condicionem tangit ipse Dionysius in Mystica theologia I cap. in principio post orationem dicens: 'Tu autem, amice Thimotee, circa mysticas visiones' (alia translatio: 'circa mysticos intellectus') 'forti contritione' (sive: 'corroborato itinere', secundum aliam translationem) 'et sensus derelinque et intellectuales operationes, et omnia sensibilia et intelligibilia et omnia existentia et non existentia, et sicut est possibile, ignote consurge ad eius unitionem, qui est super omnem substantiam et cognitionem. Et enim excessu tui ipsius et omnium irretentibili absolute, et munde ad supersubstantialem divinarum tenebrarum radium, cuncta auferens et a cunctis absolutus sursum' agens. See Dionysius, De mystica theologia, ed. A.M. Ritter (Berlin / New York: De Gruyter, 1991), 1.1, p. 142, 1. 5-11; Dionysiaca, p. 567-569.

43 Dietrich of Freiberg, De tribus difficilibus quaestionibus, ed. L. Sturlese, in Opera omnia, vol. 3. Schriften zur Naturphilosophie und Metaphysik, eds J.-D. Cavigioli et al. (Hamburg: Meiner, 1983), p. 9, l. 16-18: de principio ex parte nostri, quo immediate uniuntur beati Deo in illa gloriosa et beatifica visione, utrum videlicet hoc sit intellectus possibilis vel intellectus agens.

44 Berthold of Moosburg, Expositio, 21C, p. 83, 1. 263-273, with emphasis added: Unitas vero agens et patiens est duplex, quia vel subsistit se ipsa formaliter per essentiam, licet efficienter sit a primo dicta unitate producta, vel subsistit in alio non potens subsistere per se ipsam. Primo hic dicto modo unitas dicitur de omnibus primordialibus causis, quarum quaelibet est unitas per se perfecta. Secundo modo adhuc dicitur dupliciter, quia vel est principium causale formale eius, in quo subsistit, sicut se habet omnis unitas sive in virtutibus sive in entibus sive in vitis sive in intellectualibus hypostasibus sive in animabus - quaelibet enim istarum unitatum, licet sit quodammodo patiens, ut procedit a sua prime causa, tamen est agens, inquantum est causa totius residuae subsistentiae rei, cuius est principale principium intrinsecum formale et causale sub ordine principalis agentis; Berthold of Moosburg, Expositio, 64B, p. 193, l. 34-p. 194, l. 36: Si [unitas] est res extra animam, tunc habet rationem principii omnia sua principiata in se virtualiter continentis ita, quod est potentia omnia sua principiata, actu vero et operatione nullum. 
Berthold therefore believes, on the basis of Proclus, that the principle of individual deification is a substance whose very action is its substance, and in this sense he interprets Dionysius.

There are many declarations in this sense, in which Dionysius and Proclus are both quoted, even if Berthold underlines the transience and the difficulty of this mystical experience.

In the prologue he declares, ${ }^{45}$ in the words of Hermes Trismegistus (through Albert), that the human being (homo) "is" conjoined (subnexus, id est coniunctus, copulatus) with God. There is a certain paradox in this statement, since this conjunction is presented as a factuality but immediately afterward it is said that this conjunction "happens" ( $f i t)$, according to Dionysius, ${ }^{46}$ "through the abandonment of the senses and intellectual operations, of all the sensible and intelligible, and of all being and non-being, and in such a way that the divine man rises in a hidden way, according to his possibility", "to the union with him who transcends all substance and knowledge". But shortly afterwards Berthold returns to factuality: 47 "thus man is united with God, the true and ineffable One, through his one, that is, through the divine likeness - in fact through his one, which is the image of God by which man is capable of God himself and is united with God [...] it is the likeness of God and is God through participation", which is deification.

A similar metaphysical objectivity characterises the commentary to Proposition 129, if I understand the text correctly, in which the notion of deification is explicitly analysed:48 "All divine bodies are such through the mediation of a divinised soul, all divine souls through a divine intelligence, and all divine intelligences by participation in a divine henad: the henad is immediate deity,

45 Berthold of Moosburg, Expositio, Prologus 18, p. 27, l. 729-732: Sic ergo homo subnexus Deo vero et indicibili uni per suum unum, hoc est per divinam similitudinem - uno enim suo, quod est imago Dei, qua homo est capax ipsius Dei et conexus Deo, habet similitudinem Dei, immo est similitudo Dei et deus participatione.

46 Berthold of Moosburg, Expositio, Prol. 17, p. 26, 1. 677-682: Quod secundum Dionysium in principio Mysticae theologiae forti contritione fit per sensuum derelictionem et intelligibilium operationum et omnium sensibilium et intelligibilium et omnium existentium et non existentium et ut divinus homo ignote consurgat, sicut est possibile, 'ad eius unitionem, qui est super omnem substantiam et cognitionem. Et subiungit ad hoc necessarium esse excessum sui et omnium. See Dionysius, De mystica theologia, text quoted in note 42.

47 See note 46.

48 Berthold of Moosburg, Expositio, 129, p. 174, 1. 2-7: Omne corpus divinum per animam est divinum exdeatam, omnis autem anima divina propter divinum intellectum, omnis autem intellectus divinus secundum participationem divinae unitatis. et si quidem unum antotheon, id est ex se deus, intellectus autem divinissimus, anima autem divina, corpus autem deiforme. 
the intelligence most divine, the soul divine, the body deisimilar". Here Proclus is dealing with the vertical series, in which the distinctive property of each henad is reflected at different levels of reality (taxeis), and illustrates the relationships of dependence and participation at the metaphysical level. Berthold, applying a principle of symmetry already formulated by Dietrich, ${ }^{49}$ finds these levels in the microcosm that is the deified man:50 "in Proposition $129[\ldots]$ it has been demonstrated that in the deified man there are four [levels], that is, the divine body, the divine soul, the most divine intellect and the one or the unity that transcends the nature of the mind [Dionysius]"; "let us take the deified man as an example: [...] the absolute One, that is, God himself, participated in a separable way, is present in the intellect through an inseparable power, that is, the one, and in this way makes the intellect itself divine; and furthermore is present to the rational soul through the one and the intellect, deifying it [i.e. the rational soul] through the divine intellect itself".

The perspective is decidedly metaphysical. For Proclus the structure of the taxeis is objective, and the description of the deified man also appears to be objective. Deification is the result of the presence of the One in the soul through the determinations of power, being, life and intellect, and is a gift (datio) that "is the fundamental substratum" and therefore is constitutive of human nature. Should we therefore conclude that man is deified by the presence of God, and is not aware of this?

With regard to this awareness, Berthold affirms that it is the result of a greater or lesser separation from corporeal things (prout minus vel plus se ab his corporalibus separaverit), ${ }^{51}$ and that it is possible in this life, even if in a transitory way, "sometimes" (aliquando): "contemplating the gods [or rather the primordial causes] it is sometimes possible for the human soul, indeed for

49 See L. Sturlese, "Dietrich von Freiberg", in A. Brungs, V. Mudroch, P. Schulthess (eds), Die Philosophie des Mittelalters, vol. IV. 13. Jahrhundert (Basel: Schwabe, 2017), p. 895-911, at p. 910.

$50 \quad$ Berthold of Moosburg, Expositio, 181D, p. 223, l. 83-88: [...] per 129, ubi etiam ostensum est, quod in homine deificato sunt quattuor, scilicet corpus divinum, anima divina, intellectus divinissimus et unum sive unitas, quae etiam 'excedit mentis naturam'; Berthold of Moosburg, Expositio, 129B, p. 178, 1. 155-181: ponamus hominem deificatum pro exemplo [...]. Et sic prime unum, scilicet ex se Deus, separabiliter participatus adest intellectui per inseparabilem potentiam, scilicet per tale unum, et sic facit ipsum intellectum divinissimum; et item adest animae rationali mediante et uno et intellectu, deificans eam per ipsum intellectum divinum.

51 Berthold of Moosburg, Expositio, 197I, p. 139, 1. 220-221: In statu enim generationis potest enumeratas quinque cognitionum species exercere, prout minus vel plus se ab his corporalibus separaverit. 
us through this"; 52 "it sometimes contemplates the gods, which is nevertheless granted to a few souls";53 "as Dionysius affirms when speaking of himself and other men of exemplary holiness" and "of the holy minds of human souls" (de mentibus sanctis humanarum animarum) in this life (de contemplatione viae). ${ }^{54}$ Nevertheless, "those who study divine things become gods" (divina tractantes efficiuntur di et cognoscunt divina $)^{55}$ and exercise perfect wisdom: "The perfect wisdom of the soul is to recognize where it was born and from what source it comes". 56

All of these statements show, in my opinion, a certain difficulty in reconciling the metaphysical perspective with an eschatological perspective, that is, the different perspectives of natural providence and voluntary providence. On the one side there is the ordered, eternal cosmic theatre of the world described by Proclus, on the other there is the single actor of creation, the homo nexus Dei et mundi, who by the instrument of his own reason moves towards the discovery of his true being, transcends his rationality, and ascends to the One by acquiring divine intellect, and at the same time acts virtuously and acquires merits of eschatological relevance. In the unum animae the orders of the two providences are unified, and it is therefore no wonder that Proclus, a pagan philosopher, reached unitive deification as it was understood Dionysius and Berthold: "deification is unitas with God, simplicity that rejects any diversity of multiplicity".57

52 Berthold of Moosburg, Expositio, 185I, p. 25, l. 376-379: necessarium est animas, quae semper sunt statutae extra se ipsas et supra se ipsas et sic totae deifactae, incessanter unitate supermentali contemplari ipsos deos, cum hoc sit animae partiali, prout est in generatione, immo nobis per eam possibile aliquando.

53 Berthold of Moosburg, Expositio, $185 \mathrm{M}$, p. 28, 1. 457-471: [...] ideo non semper contemplatur deos, licet aliquando. Quod tamen paucis conceditur animabus [...].

54 Berthold of Moosburg, Expositio, 202C, p. 185, l. 138-144: [...] de contemplatione viae subiungit [...]; 185G, p. 24, l. 329-331: Et licet praedicta verba Dionysii sint dicta de mentibus sanctis humanarum animarum, tamen proportionaliter eminentiori modo applicari possunt ad animas semper intelligentes.

55 Berthold of Moosburg, Expositio, Praeambulum C, p. 65, l. 419-420.

56 Berthold of Moosburg, Expositio, 206F, p. 223, l. 237-238: animae enim, dum corpore utitur, haec est perfecta sapientia, ut, unde orta sit, de quo fonte venerit, recognoscat.

57 Berthold of Moosburg, Expositio, 129B, p. 177, 1. 133-137: 'Deificatio autem' secundum Dionysium 1 cap. Ecclesiasticae hierarchiae 'est ad Deum, sicut est possibile, et assimilatio et unitio' (alia translatio: 'et similitudo et unitas'). 'Similitudo vero est rerum differentium eadem qualitas' vel proprietas. Unitas autem est simplicitas omnem diversitatem multitudinis seu diversam multitudinem refutans. 


\section{Bibliography}

\section{Manuscripts}

Basel, Universitätsbibliothek, F.IV.31.

\section{Primary Sources}

Berthold of Moosburg, Expositio super Elementationem theologicam Procli. Prologus. Propositiones 1-13, eds M.R. Pagnoni-Sturlese, L. Sturlese, Hamburg, Meiner, 1984.

Berthold of Moosburg, Expositio super Elementationem theologicam Procli. Propositiones 14-34, eds L. Sturlese, M.R. Pagnoni-Sturlese, B. Mojsisch, Hamburg, Meiner, 1986.

Berthold of Moosburg, Expositio super Elementationem theologicam Procli. Propositiones $35^{-65}$, ed. A. Sannino, Hamburg, Meiner, 2001.

Berthold of Moosburg, Expositio super Elementationem theologicam Procli. Propositiones 66-107, ed. I. Zavattero, Hamburg, Meiner, 2003.

Berthold of Moosburg, Expositio super Elementationem theologicam Procli. Propositiones 108-135, ed. F. Retucci, Hamburg, Meiner, 2011.

Berthold of Moosburg, Expositio super Elementationem theologicam Procli. Propositiones 136-159, ed. F. Retucci, Hamburg, Meiner, 2007.

Berthold of Moosburg, Expositio super Elementationem theologicam Procli. Propositiones 16o-183, eds U.R. Jeck, I.J. Tautz, Hamburg, Meiner, 2003.

Berthold of Moosburg, Expositio super Elementationem theologicam Procli. Propositiones 184-211, ed. L. Sturlese, Hamburg, Meiner, 2014.

Dietrich of Freiberg, Opera omnia, vol. ı. Schriften zur Intellekttheorie, ed. B. Mojsisch, Hamburg, Meiner, 1977.

Dietrich of Freiberg, Opera omnia, vol. 3. Schriften zur Naturphilosophie und Metaphysik, eds J.-D. Cavigioli et al., Hamburg, Meiner, 1983.

Dionysiaca, recueil donnant l'ensemble des traductions latines des ouvrages attribués au Denys de l'Aréopage, ed. Ph. Chevallier, Bruges, Desclée de Brouwer, 1937.

Dionysius the ps.-Areopagite, De divinis nominibus, ed. B.R. Suchla, Berlin / New York, De Gruyter, 1990.

Dionysius the ps.-Areopagite, De coelesti hierarchia, De ecclesiastica hierarchia, De mystica theologia, Epistulae, eds G. Heil, A.M. Ritter, Berlin / New York, De Gruyter, 1991.

Enchiridion Symbolorum, Definitionum et declarationum de rebus fidei et morum, eds H. Denzinger, A. Schönmetzer, 36th ed., Barcelona / Freiburg im Breisgau / Roma, Herder, 1976.

Proclus, Tria opuscula (De providentia, libertate, fato), ed. H. Boese, Berlin, De Gruyter, 196o.

Proclus, The Elements of Theology, ed. E.R. Dodds, 2nd ed., Oxford, Clarendon Press, 1963. 


\section{Secondary Literature}

Beierwaltes, W., "Der Begriff des unum in nobis bei Proklos", in P. Wilpert (ed.), Die Metaphysik im Mittelalter, ihr Ursprung und ihre Bedeutung, Berlin / New York, De Gruyter, 1963, p. 255-266.

Gersh, S., "Berthold von Moosburg and the Content and Method of Platonic Philosophy", in J. Aertsen, K. Emery, Jr., A. Speer (eds), Nach der Verurteilung von 1277. Philosophie und Theologie an der Universität von Paris im letzten Viertel des 13. Jahrhunderts, Berlin / New York, De Gruyter, 2001, p. 493-503.

King, E., "Supersapientia. A Study of the Expositio super Elementationem theologicam Procli of Berthold von Moosburg", PhD diss., University of Cambridge, 2016.

Ludueña, E., La recepción de Eriúgena en Bertholdo de Moosburg. Un aporte sobre la Escuela de Colonia, Saarbrücken, Publicia, 2013.

Porreca, D., "Hermes Trismegistus in Thomas of York. A 13th-Century Witness to the Prominence of an Ancient Sage", in Archives d'histoire doctrinale et littéraire du Moyen Âge 72(2005), p. 147-275.

Retucci, F., "Magister Thomas Anglicus minor", in Berthold of Moosburg, Expositio super Elementationem theologicam Procli. Propositiones 136-159, ed. F. Retucci, Hamburg, Meiner, 2007, p. xxiii-xxxix.

Sturlese, L., Homo divinus. Philosophische Projekte in Deutschland zwischen Meister Eckhart und Heinrich Seuse, Stuttgart, Kohlhammer, 2007.

Sturlese, L., "Dietrich von Freiberg", in A. Brungs, V. Mudroch, P. Schulthess (eds), Die Philosophie des Mittelalters, vol. IV. 13. Jahrhundert, Basel, Schwabe, 2017, p. 895-911. 